\title{
Rapid axillary bud proliferation and ex vitro rooting of Eupatorium triplinerve
}

\author{
K.P. MARTIN \\ Department of Biotechnology, University of Calicut, Kerala-673 635, India
}

\begin{abstract}
Effective protocol was established for micropropagation of the medicinal plant Eupatorium triplinerve Vahl through rapid axillary bud proliferation and ex vitro rooting. Murashige and Skoog (MS) medium fortified with $8.87 \mu \mathrm{M}$ benzylaminopurine (BAP) and $2.46 \mu \mathrm{M}$ indole-3-butyric acid (IBA) was the best for axillary bud proliferation and developed a mean of 8.1 shoots per node. Excision and culture of the node segments of the in vitro shoots on medium supplemented with the same concentration of growth regulators developed more than 30 shoots within $40 \mathrm{~d}$. Shoot multiplication did not exhibit decrease in the number of shoots even at $7^{\text {th }}$ subculture. Dipping of the basal end of shoots in $2.46 \mu \mathrm{M}$ IBA solution for $10 \mathrm{~d}$ induced roots and its transfer to small pots facilitated the survival of all rooted shoots $(100 \%)$. Ex vitro rooting by direct transfer of the shoots from multiplication medium showed $92 \%$ survival.
\end{abstract}

Additional key words: ayapana, benzylaminopurine, clonal propagation, indolc-3-butyric acid.

Eupatorium triplinerve Vahl (Syn. E. ayapana Vent.) belonging to the family Asteraceae, commonly known as ayapana, is a native of America. Ayapana is compared to chamomile in its medicinal properties. Micropropagation through axillary bud multiplication has been reported in many medicinal plants (Abrie and van Staden 2001, Dias et al. 2002, Salvi et al. 2002). No in vitro propagation of this valuable medicinal plant has been reported so far. In the present study, clonal propagation of Eupatorium triplinerve through axillary bud multiplication using tap water and commercial sugar and ex vitro rooting was accomplished.

Young shoots (with 2 - 4 nodes) of Eupatorium triplinerve Vahl were collected from flowering mature plants grown in Calicut University Botanical Garden. They were washed under running tap water followed by a detergent Extran $(5 \% \mathrm{v} / \mathrm{v})$ for $5 \mathrm{~min}$. After repeated wash with double distilled water, young shoots were surface sterilized using $0.5 \%(\mathrm{~m} / \mathrm{v})$ mercuric chloride solution for $7-10 \mathrm{~min}$. After thorough washing with sterile double distilled water, single node segments of $1.0-1.5 \mathrm{~cm}$ were cultured on sterile medium consisting of the salts and vitamins of Murashige and Skoog (1962, MS). Commercial-grade sucrose at $3 \%$ was used as the carbon source. The medium was gelled with $0.6 \%$ agar. Basal medium was supplemented with different growth regulators at different concentrations either singly or in combination (Table 1). In vitro root induction was carried out on full strength growth regulator-free or on half strength MS solid medium without or with auxins (Table 2). All the media were prepared using tap water. The $\mathrm{pH}$ of the medium on all cases was adjusted to 5.8 before autoclaving at a pressure of $1.06 \mathrm{~kg} \mathrm{~cm}^{-2}$. The cultures were incubated at $25 \pm 2{ }^{\circ} \mathrm{C}$ with 16 -h photoperiod under irradiance $25 \mu \mathrm{mol} \mathrm{m} \mathrm{m}^{-2} \mathrm{~s}^{-1}$ (white fluorescent tubes). All the experiments were set up in a completely randomised design. Twenty cultures were raised for each treatment and all experiments were repeated twice (total of 60 cultures). Means were compared using Duncan's multiplication range test (Duncan 1955).

Received 2 August 2002, accepted 3 September 2003.

Abbreviations: BAP - 6-benzylaminopurine; IAA - indole-3-acetic acid; IBA - indole-3-butyric acid; Kn - kinctin; MS - Murashige and Skoog; NAA - $\alpha$-naphthaleneacetic acid.

Acknowledgements: Gratefully acknowledge the Head and Co-Ordinator, Department of Biotechnology, University of Calicut for providing facilities for the work.

Fax: $(+91)$ 4942400269, e-mail: martin $a$ sify.com 
For ex vitro rooting, the well-grown shoots from the shoot multiplication medium were directly transferred to small pots containing soil and sand $(1: 1)$ and also by transferring to pots after dipping the basal end of shoots in IBA solution for $10 \mathrm{~d}$.

Growth regulator-free MS medium facilitated the initiation of axillary buds of the node explants. MS medium with different concentrations of 6-benzylaminopurine (BAP) and kinetin (Kn) individually or in combination and also in combination with auxins [ $\alpha$-naphthaleneacetic acid (NAA), indole-3-butyric acid (IBA), and indole-3-acetic acid (IAA)] also resulted in initiation of axillary buds (Table 1). BAP at $8.87 \mu \mathrm{M}$ in combination with IBA at $2.46 \mu \mathrm{M}$ was the best for axillary bud multiplication. On this medium, both the axillary buds were initiated within $10 \mathrm{~d}$ and developed mean of 8.1 shoots per node explant within $40 \mathrm{~d}$ (Table 1). The developed shoots attained more than $6 \mathrm{~cm}$ height within $40 \mathrm{~d}$. Axillary buds at the nodes of the in vitro developed shoots also underwent initiation and growth. These shoots also attained growth sufficient (more than $3 \mathrm{~cm}$ ) for the transfer to root induction. Upon BAP and IBA containing medium, the shoots were healthier longer than that on BAP alone. Present investi-

Table 1. Axillary bud multiplication of Eupatorium triplinerve on MS medium enriched with different growth regulators. Means followed by different letters are significantly different at $5 \%$ level. $n=60$. Growth period $40 \mathrm{~d}$.

\begin{tabular}{|c|c|c|c|c|c|c|}
\hline $\begin{array}{l}\text { BAP } \\
{[\mu \mathrm{M}]}\end{array}$ & $\begin{array}{l}\mathrm{Kn} \\
{[\mu \mathrm{M}]}\end{array}$ & $\begin{array}{l}\text { IBA } \\
{[\mu \mathrm{M}]}\end{array}$ & $\begin{array}{l}\mathrm{IAA} \\
{[\mu \mathrm{M}]}\end{array}$ & $\begin{array}{l}\mathrm{NAA} \\
{[\mu \mathrm{M}]}\end{array}$ & $\begin{array}{l}\text { Response } \\
{[\%]}\end{array}$ & $\begin{array}{l}\text { Number } \\
\text { of shoots } \\
{\left[\text { node }^{-1}\right]}\end{array}$ \\
\hline 0.00 & 0.00 & 0.00 & 0.00 & 0.00 & $74.2 \mathrm{e}$ & $1.9 \mathrm{f}$ \\
\hline 2.22 & & & & & $85.5 \mathrm{~cd}$ & $2.3 \mathrm{ef}$ \\
\hline 4.44 & & & & & $93.1 \mathrm{~b}$ & $2.9 \mathrm{e}$ \\
\hline 6.66 & & & & & $95.7 \mathrm{ab}$ & $3.9 \mathrm{~cd}$ \\
\hline 8.87 & & & & & $84.4 \mathrm{~d}$ & $4.3 \mathrm{~cd}$ \\
\hline 13.20 & & & & & $95.2 \mathrm{ab}$ & $2.6 \mathrm{e}$ \\
\hline 22.10 & & & & & $93.5 b$ & $0.9 \mathrm{~g}$ \\
\hline & 2.32 & & & & $75.4 \mathrm{e}$ & $1.8 \mathrm{f}$ \\
\hline & 4.65 & & & & $82.8 \mathrm{~d}$ & $2.1 \mathrm{ef}$ \\
\hline & 6.97 & & & & $95.3 \mathrm{ab}$ & $3.3 \mathrm{~d}$ \\
\hline & 9.29 & & & & $92.5 b$ & $3.1 \mathrm{de}$ \\
\hline & 13.90 & & & & $91.6 b$ & $2.8 \mathrm{e}$ \\
\hline 8.87 & 0.46 & & & & $96.2 \mathrm{a}$ & $2.8 \mathrm{e}$ \\
\hline 8.87 & 2.32 & & & & $94.6 \mathrm{~b}$ & $3.8 \mathrm{~d}$ \\
\hline 8.87 & 4.65 & & & & $89.0 \mathrm{c}$ & $3.2 \mathrm{~d}$ \\
\hline 8.87 & & 0.49 & & & $97.3 \mathrm{a}$ & $6.7 b$ \\
\hline 8.87 & & 2.46 & & & $98.5 \mathrm{a}$ & $8.1 \mathrm{a}$ \\
\hline 8.87 & & 4.90 & & & $94.2 b$ & $6.2 b$ \\
\hline 8.87 & & & 0.57 & & $93.1 \mathrm{~b}$ & $5.3 c$ \\
\hline 8.87 & & & 2.85 & & $94.4 \mathrm{~b}$ & $6.5 b$ \\
\hline 8.87 & & & 5.71 & & $97.1 \mathrm{a}$ & $5.1 \mathrm{c}$ \\
\hline 8.87 & & & & 0.54 & $84.7 \mathrm{~d}$ & $5.4 \mathrm{c}$ \\
\hline 8.87 & & & & 2.69 & $93.8 \mathrm{~b}$ & $4.0 \mathrm{~cd}$ \\
\hline 8.87 & & & & 5.37 & $91.1 b c$ & $3.4 \mathrm{~d}$ \\
\hline
\end{tabular}

gation was in agreement with the earlier reports that low concentrations of an auxins can positively modify the shoot induction frequency in combination with cytokinins. Synergistic effect of BAP and an auxin in multiplication and growth of shoots has been exemplified on medicinal plants viz. Hemidesmus indicus (Sreekumar et al. 2000), Holostemma ada-kodien (Martin 2002) and turmeric (Salvi et al. 2002). Excision and culture of the node segments from the in vitro derived shoots on MS medium supplemented with the same concentrations of BAP $(8.87 \mu \mathrm{M})$ and IBA $(2.46 \mu \mathrm{M})$ developed more than 30 shoots within $40 \mathrm{~d}$. Subsequent culture increased the rate of shoot multiplication and no decline of shoots was observed up to $7^{\text {th }}$ subculture.

Twenty per cent shoots spontaneously developed roots on shoot multiplication medium. Shoots without roots were transferred to full or half strength growth regulator-free medium for root induction. Half strength growth regulator-free medium was superior to full strength medium for root development. Auxins at lower concentrations facilitated better rooting (Table 2). Among the different auxins, IBA was superior to IAA and NAA. Half strength MS medium fortified with $2.46 \mu \mathrm{M}$ IBA was the best for in vitro root development (Table 2). In root induction efficacy of auxins, IAA followed IBA (Table 2). NAA was inferior and favoured callus formation at the base. Efficacy of IBA at lower concentrations in in vitro rooting has been reported in medicinal plants like Swainsona salsula (Yang et al. 2001) and Plumbago spp. (Das and Rout 2002). In vitro rooted healthy shoots transferred directly to small pots containing soil and sand $(1: 1)$ revived growth after $15 \mathrm{~d}$ of transplantation and $100 \%$ plantlets survived in field conditions.

Table 2. In vitro rooting of Eupatorium triplinerve on halfstrength MS medium fortified with different auxins. Means followed by different letters are significantly different at $5 \%$ level, $n=60$. Growth period $30 \mathrm{~d}$.

\begin{tabular}{|c|c|c|c|c|}
\hline $\begin{array}{l}\text { IBA } \\
{[\mu \mathrm{M}]}\end{array}$ & $\begin{array}{l}\text { IAA } \\
{[\mu \mathrm{M}]}\end{array}$ & $\begin{array}{l}\text { NAA } \\
{[\mu \mathrm{M}]}\end{array}$ & Response [\%] & $\begin{array}{l}\text { Number of roots } \\
{\left[\text { shoot }^{-1}\right]}\end{array}$ \\
\hline $\begin{array}{l}0.00 \\
0.49 \\
2.46 \\
4.90\end{array}$ & $\begin{array}{l}0.57 \\
2.85 \\
5.71\end{array}$ & $\begin{array}{l}0.54 \\
2.69 \\
5.37\end{array}$ & $\begin{array}{r}81.3 \mathrm{~d} \\
92.6 \mathrm{~b} \\
100.0 \mathrm{a} \\
100.0 \mathrm{a} \\
100.0 \mathrm{a} \\
100.0 \mathrm{a} \\
100.0 \mathrm{a} \\
93.7 \mathrm{~b} \\
87.9 \mathrm{c} \\
87.3 \mathrm{c}\end{array}$ & $\begin{array}{r}4.4 \mathrm{f} \\
7.5 \mathrm{~d} \\
11.7 \mathrm{a} \\
10.3 \mathrm{~b} \\
6.3 \mathrm{e} \\
10.1 \mathrm{~b} \\
9.5 \mathrm{c} \\
6.2 \mathrm{e} \\
7.9 \mathrm{~d} \\
6.4 \mathrm{e}\end{array}$ \\
\hline
\end{tabular}

Ex vitro rooting was also tried in the present study. In the first method, the basal portion of rootless shoots was kept in different concentrations of IBA solution for $10 \mathrm{~d}$. 
Of the different concentrations of IBA solution, $2.46 \mu \mathrm{M}$ was most effective and developed a mean of 12.4 roots per shoot. Lower $(0.49 \mu \mathrm{M})$ and higher $(4.9 \mu \mathrm{M})$ concentration of IBA proved to be less efficient (developed mean of 8.3 and 10.5 roots per shoots respectively). Shoots rooted through this method transplanted to small pots exhibited $100 \%$ survival. Successful induction of rooting by basal dipping of in vitro developed shoots in IBA solution for short periods has been reported in Decalepis hamiltonii (Reddy et al. 2001), Ceratonia siliqua (Romano et al. 2002) and Simmondsia chinensis (Agrawal et al. 2002). In the second method of ex vitro rooting, the healthy shoots excised from the shoot multiplication medium were directly transferred to small pots containing soil and sand

\section{References}

Abrie, A.L., van Staden, J.: Micropropagation of the endangered Aloe polyphylla. - Plant Growth Regul. 33: $19-$ 23. 2001 .

Agrawal. V., Prakash, S., Gupta, S.C.: Effective protocol for in vitro shoot production through nodal explants of Simmondsia chinensis. - Biol. Plant. 45: 449-453, 2002.

Bhatia. N.P.. Bhatia. P.. Ashwath, N.: Ex vitro rooting of micropropagated shoots of Stackhousia tryonii. - Biol. Plant. 45: 441-444. 2002.

Das, G.. Rout, G.R.: Direct plant regeneration from leaf explants of Plumbago species. - Plant Cell Tissue Organ Cult. 68: 311-314, 2002.

Debergh, P.C., Maene, L.J.: A scheme for the commercial propagation of ornamental plants by tissue culture. Scientia Hort. 14: 335-345, 1981.

Dias, M.C.. Almeida, R., Romano, A.: Rapid clonal multiplication of Lavandula viridis L'Hér through in vitro axillary shoot proliferation. - Plant Cell Tissue Organ Cult. 68: 99-102, 2002.

Duncan, D.B.: Multiple range and multiple F-tests. - Biometrics 11: $1-42,1955$.

Economou, A.S., Spanoudaki, M.J.: In vitro propagation of gardenia. - Hort. Sci. 20: 213, 1985.

Martin, K.P.: Rapid propagation of Holostemma ada-kodien Schult., a rare medicinal plant, through axillary bud
(1:1). Of the 150 plants transferred, 138 plants $(92 \%)$ survived. Rooting ex vitro has also been reported in Gardenia jasminoides (Economou and Spanoudaki 1985), Actinidia deliciosa (Pedroso et al. 1992), and Stackhousia tryonii (Bhatia et al. 2002). The shoots revived growth within $20 \mathrm{~d}$ after transfer. In view of Debergh and Maene (1981) ex vitro rooting accounts $35-75 \%$ reduction of the total cost of plants propagated through tissue culture.

Present protocol facilitates cost effective production of more than 60000 plantlets within $150 \mathrm{~d}$ starting from a single node explant using single medium and enables to meet the need in time without the annihilation of the natural resources of this valuable medicinal plant.

multiplication and indirect organogenesis. - Plant Cell Rep. 21: 112-117; 2002 .

Murashige. T.. Skoog, F.: A revised medium for rapid growth and bioassays for tobacco tissue cultures. - Physiol. Plant. 15: 473-497. 1962.

Pedroso, C. Oliveira. M.. Pais, S.S.: Micropropagation and simultaneous rooting of Actinidia deliciosa var. "Hayward'. - Hort. Sci. 27: 443-445, 1992

Romano. A.. Barros. S.. Martins-Loucão, M.A.: Micropropagation of the Mediterranean tree Ceratonia siliqua. - Plant Cell Tissue Organ Cult. 68: 35-41, 2002.

Reddy, O.B., Giridhar, P., Ravishankar, G.A.: In vitro rooting of Decalepis hamiltonii Wight \& Arn., an endangered shrub, by auxins and root-promoting agents. - Curr. Sci. 81: 1479-1482. 2001.

Salvi, N.D., George. L., Eapen, S.: Micropropagation and field evaluation of micropropagated plants of turmeric. - Plant Cell Tissue Organ Cult. 68: 143-151, 2002.

Sreekumar, S., Seeni, S., Pushpangadan, P.: Micropropagation of Hemidesmus indicus for cultivation and production of 2-hydroxy 4-methoxy benzaldehyde. - Plant Cell Tissue Organ Cult. 62: 211-218, 2000.

Yang. J., Hu. Z., Guo, G.Q., Zheng, G.C.: In vitro plant regeneration from cotyledon explants of Swainsona salsula Taubert. - Plant Cell Tissue Organ Cult. 66: 35-39. 2001. 